\title{
SOLID WASTE MANAGEMENT: CHALLENGES AND PRACTICES IN THE NEPALESE CONTEXT
}

\author{
Amrit Maharjan', Singh Bahadur Khatri ${ }^{1}$, Luna Thapa1, Ramesh Raj Pant ${ }^{1 *}$, Pankaj \\ Pathak $^{2}$, Youb Raj Bhatta ${ }^{1}$, Kedar Rijal ${ }^{1}$, and Kiran Bishwakarma ${ }^{3}$ \\ ${ }^{1}$ Central Department of Environmental Science, Institute of Science and Technology, Tribhuvan \\ University, Kathmandu, Nepal \\ ${ }^{2}$ Department of Environmental Science, SRM University, Andhra Pradesh, India \\ ${ }^{3}$ Institute of Tibetan Plateau Research, Chinese Academy of Sciences, Beijing 100101, China \\ *For Correspondence: rpant@cdes.edu.np (R.R. Pant).
}

\begin{abstract}
Municipal Solid Waste is one of the demanding environmental challenges faced by many municipalities in Nepal. Current practices and systems in Nepal being unable to deal with the increasing volumes of waste generated by an increasing urban population and its impact on the environment and public health. This paper reviewed the challenges, practices and discusses key policies, legislative and institutional provisions made by the government regarding solid waste management in Nepal. Both published and unpublished documents, reports; articles and books were collected, reviewed, and analyzed. The result shows that an appropriate legal provision including policy and strategic framework needs to be developed for three tiers of government such as federal, provincial, and local. The initiatives of local governments and the public could play a significant role in managing solid wastes. Thus, strengthening the capacity of local governments is indispensable, as primarily they are mandated to provide solid waste management. The public-private partnership offers opportunities for operational efficiency and cost-effectiveness. In summary, for the environment-friendly management of solid wastes, academia could contribute a supportive role in developing and reforming policy, strategy, and guidelines and, strengthening the capacity of concerns at all levels.
\end{abstract}

Key words: Environmental challenges, legislation, local government, municipal solid waste

\section{INTRODUCTION}

Municipal solid waste (MSW) is an aggregate of unwanted and discarded materials that are generated in daily activities. The issue of solid waste is one of the greatest concerns of contemporary societies and a challenge to public authorities (Goncalves et al., 2018). In a global scenario, $54 \%$ of the world's population currently lives in urban areas that are expected to increase to $66 \%$ by 2050 (U.N., 2015). The
MSW generation increases with population growth, rapid urbanization, and rises in the community living standard as well as consumption patterns (Guerrero et al., 2013). The income levels, socio-cultural patterns, and climatic factors play a significant role in waste generation rates (Wilson et al., 2015).

Also, the unscientific handling of the MSW degrades the urban environment and causes health hazards (Joshi and Ahmed, 2016). Around the world 1.3 billion tons of solid 
waste is generated per year, amounting to a footprint of 1.2 kilograms per person per day. It is expected to rise to 2.2 billion tons and generating waste of about $1.42 \mathrm{~kg}$ per person per day in 2025 (Hoornweg \& Bhada, 2012). Most of the cities are facing challenges in solid waste management due to the complex composition of waste and poor effective handling methods (Omari et al., 2015). Asian countries are facing increasing difficulties to treat waste and health impacts, social and environmental risks in addition to the increasing demand for resource recovery (Abduli, 1995; Akenji et al., 2011).

Solid waste management (SWM) is one of the major problems for many urban areas in Nepal. Effective solid waste management is a major challenge in cities with high population density including Kathmandu, Lalitpur, Biratnagar, Pokhara, etc. (Asian Development Bank, 2013). Also, various ways of lifestyles, social religious, cultures, and traditions have made difficulties in the eco-friendly way of the SWM in Nepal. In Nepal, household waste generated about 1,435 tons / day and 524,000 tons/year. The generation of solid waste ranges from $0.3 \mathrm{~kg} /$ day to $1.0 \mathrm{~kg}$ / day. The municipal composition of household waste consists of a large number of organic wastes $66 \%$, 12\% plastics, 9\% paper products, $3 \%$ metals, and 5\% others (Asian Development Bank, 2013). Interestingly, the highest amount of municipal wastes is generated from the major urban centers from the Kathmandu valley which is about 620 tons/day (Shrestha, et al., 2014).

Most of the generated wastes are disposed of in landfill sites (Shrestha et al., 2014). The current status of the SWM practices in Nepal includes composting, disposal, landfilling, burning, etc. However, the scientific and environmentfriendly way of waste management practices in Nepal is still lagging (Dangi et al., 2017).

The federal system gives the provincial and local governments authority to determine their policies and manage the local resources for development, including the waste management policies provision on schedule 6-9 in the constitution of Nepal, 2015. In Nepal, the federal laws and policies provide a framework to set up municipal laws and regulations and to establish and implement the MSW management system. Federalism has transformed the responsibility to the local levels according to the constitution of Nepal, 2015. Despite the long history of the enactment of solid waste laws (e.g., before thirty years: Solid Waste and Resource Mobilization Act, 1986), the problem of solid waste management is still on the surface (Rijal and Sapkota, 2014; Dangi et al., 2017). More importantly, urban waste management remains unsatisfactory despite the policy and legal frameworks both in rural and urban areas of Nepal (ICIMOD, 2007). The major laws related to the SWM are Environmental Protection Acts, 2019; Solid Waste Management Act, 2011; Labour Act, 2017; The Public Health Service Act, 2018; Industrial Enterprises Act, 2017; Solid Waste Management Rules, 2013.

Despite significant development in social, economic, and environmental sectors, especially in the urban areas the current solid waste management systems are inefficient, with waste harming human and environmental health, and the economy. Besides, there are no special policies at local and regional levels even after the restructuring of the federal government. Thus, there is an urgent need to move to more sustainable solid waste management practices at local levels, and this requires new management systems and waste management facilities, which should be led by local authorities according to the present legal provisions. Under the changing context of the political and administrative sectors, the local governments have a key role in managing the wastes in environment-friendly ways. This 
paper reviews the challenges, barriers, and opportunities and it is mainly intended to assess the current scenarios including challenges and practices, and future perspectives of solid waste management in Nepal focusing on the legal aspects.

\section{MATERIALS AND METHODS}

The method used for the study is based on a literature review which was composed of different articles in journals till 2018 in the AGORA, OARE, Nepjol, Science Direct database, and in specific SAGE Publications journals. Different project reports of development partners such as The Asian Development Bank (ADB), The World Bank (WB), and The World Health Organization (WHO) were also reviewed. The main sources of regulatory and legal frameworks on Solid waste were obtained from the websites of the Nepal Law Commission (www.lawcommission.gov.np). The main literature search consists of 'waste', 'policies', and 'different processing methods. Some studies were done through the reference list of these articles and Google search was also used to search special reports or conference proceedings. The major urban areas where the present study has focused on through literature review are illustrated in fig. 1.

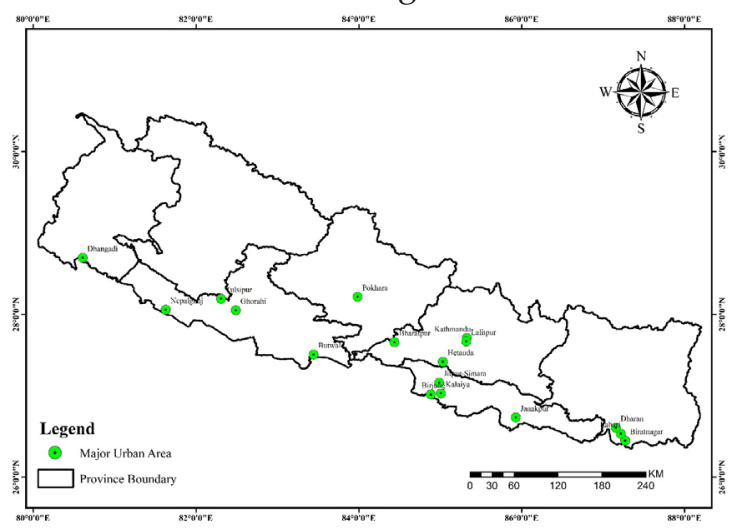

Figure 1: Major urban (6 metropolitans and 11 submetropolitan cities) areas of Nepal

\section{RESULTS AND DISCUSSION}

\section{Solid Waste Management in Nepal}

Nepal is decentralized into the federal government with 7 provinces, 77 districts, 6 metropolitans' cities, 11sub-metropolitans' cities, 276 municipalities, and 460 rural municipalities. Municipal solid waste management (MSWM) is one of the major responsibilities of municipal governments and is the major challenging issue (Shakya and Tuladhar, 2013). Currently, there were no efficient systems for the management, storage, collection, and transportation of solid waste in the municipality of Nepal. The municipalities have not been able to collect and dispose of the enormous quantity of waste being generated (Narayana, 2009). Out of the total waste generated $<50 \%$ is collected while most of the waste is haphazardly dumped (Shakya and Tuladhar, 2013). Municipalities are giving preferences only on collecting the waste and dumping it. The principle of $3 R$ (reduction, re-use and recycle) is not prioritized by the municipalities for effective sustainable waste management. Although small urban centers were declared to be municipalities, there is still a lack of infrastructural, technical, and financial resources to tackle the problems of waste management (Practical Action, 2008). Table 1 shows that Kathmandu has the highest solid waste average per capita of $441.61 \mathrm{gm} /$ capita/day. Similarly, the population of the Jitpur-Simara was found to be lowest among the 17 major cities with a $120 \mathrm{gm} /$ capita/day solid waste average per capita.

The problems of waste management at the local level is caused due to unavailability of sanitary landfill sites, lack of composting facilities, and 
Table 2 : Characterization and statistical analysis of household waste generation in major cities of Nepal

\begin{tabular}{lllll}
\hline \multirow{2}{*}{ S.N. } & \multirow{2}{*}{ Cities } & Characteristics & \\
\cline { 3 - 5 } & Kiodegradable $(\%)$ & Non-biodegradable $(\%)$ & Others $(\%)$ \\
\hline 1 & Kathmandu & 64.24 & 34.69 & 1.15 \\
2 & Biratnagar & 85.77 & 12.91 & 1.32 \\
3 & Birjung & 58.48 & 32.2 & 9.32 \\
4 & Bharatpur & 78.96 & 20.61 & 0.43 \\
5 & Lalitpur & 77.94 & 19.2 & 2.86 \\
6 & Pokhara & 62.65 & 35.27 & 1.63 \\
7 & Itahari & 61.23 & 35.45 & 3.32 \\
8 & Dharan & 58.34 & 39.18 & 2.48 \\
9 & Janakpur & 71.53 & 28.47 & 0.00 \\
10 & Kalaiya & 66.60 & 14.71 & 18.69 \\
11 & Jitpur-Simara & 80 & 16 & 4 \\
12 & Hetauda & 50.93 & 43.28 & 5.79 \\
13 & Butwal & 74.60 & 21.1 & 4.30 \\
14 & Ghorahi & 80.63 & 17.69 & 1.68 \\
15 & Tulsipur & 85.87 & 14.13 & 0.00 \\
16 & Nepalgunj & 76.27 & 23.06 & 0.67 \\
17 & Dhangadi & 68.13 & 29.22 & 2.65 \\
\hline
\end{tabular}

Source: ADB (2013)

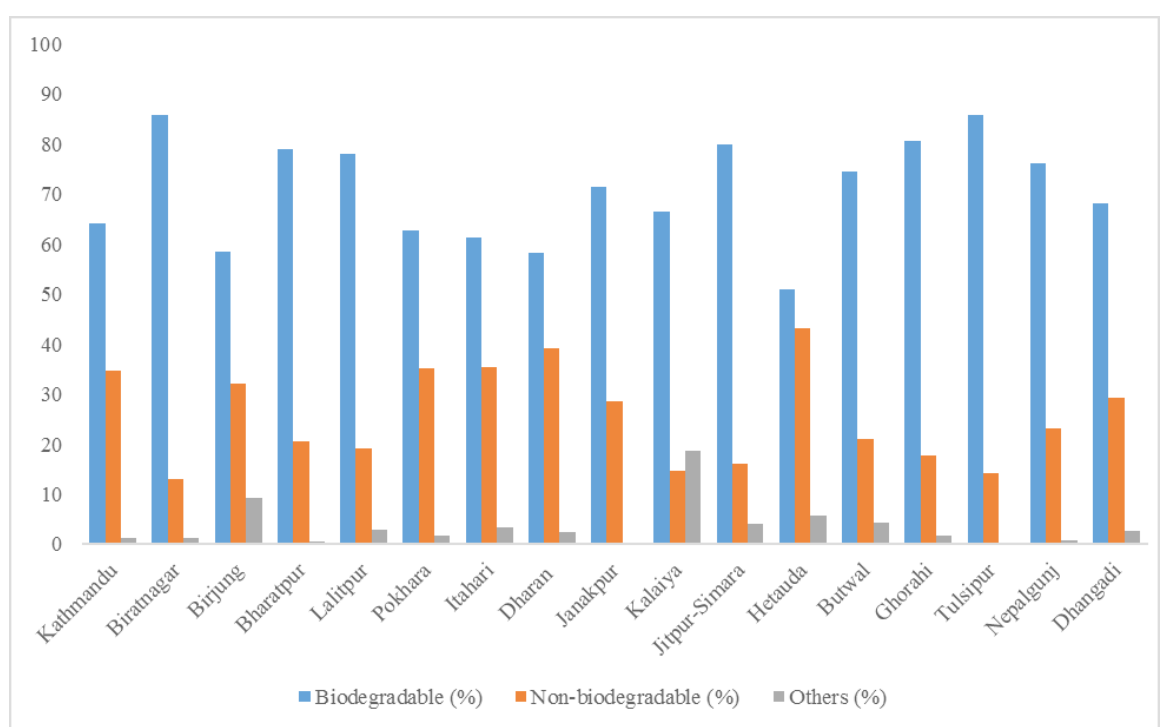

Figure 2: Characterization and statistical analysis of household waste generation in major cities of Nepal 
Solid Waste Management: Challenges and Practices ...

Table 3: Characterization and statistical analysis of institutional waste generation in major cities of Nepal

\begin{tabular}{lllll}
\hline \multirow{2}{*}{ S.N } & \multirow{2}{*}{ Cities } & Characteristics & & \\
\cline { 3 - 5 } & & Biodegradable (\%) & Non-biodegradable (\%) & Others (\%) \\
\hline 1 & Kathmandu & 20.29 & 76.36 & 3.35 \\
2 & Biratnagar & 41.56 & 56.9 & 1.54 \\
3 & Birjung & 16.99 & 71.72 & 11.29 \\
4 & Bharatpur & 30.84 & 68.94 & 0.22 \\
5 & Lalitpur & 14.53 & 65.83 & 19.64 \\
6 & Pokhara & 26.19 & 73.49 & 0.32 \\
7 & Itahari & 25.64 & 67.98 & 6.38 \\
8 & Dharan & 22.39 & 70.14 & 7.47 \\
9 & Janakpur & 11.23 & 68.96 & 19.81 \\
10 & Kalaiya & 9.98 & 56.69 & 33.33 \\
11 & Jitpur-Simara & 17 & 70 & 13 \\
12 & Hetauda & 8.01 & 82.38 & 9.61 \\
13 & Butwal & 24.48 & 52.15 & 23.37 \\
14 & Ghorahi & 21.38 & 63.64 & 14.98 \\
15 & Tulsipur & 2.94 & 79.8 & 17.26 \\
16 & Nepalgunj & 39.30 & 59.17 & 1.53 \\
17 & Dhangadi & 16.36 & 71.47 & 12.17 \\
\hline
\end{tabular}

Source: ADB (2013)

Current waste management practices in Nepal

\section{Waste collection}

According to the World Bank, based on the estimation the amount of waste collected in Nepal is reported to be approximately 700,000 tons per year. Most of the municipalities do not have reliable data on the total amount of waste they collect. The most common waste collection mechanism practiced in Nepal is roadside collection which is a very common practice in Nepal. Street sweeping for the collection of waste is an important activity in the waste management system (Shakya and Tuladhar, 2013). According to the information provided in the survey, it is found that some municipalities are practicing door-to-door collection waste from all households through the vehicle. This collection system is carried out by a municipality in coordination with other private and community sectors. Bio-degradable and non-biodegradable waste are not segregated in most of the municipalities. Different types of wastes are collected in the same garbage. However, the special wastes of hospitals are being managed out by a private organization. In the case of a few other municipalities, there prevails segregation of waste at the source as well as the collection of biodegradable and nonbiodegradable waste is done separately. The recycled wastes are segregated properly by the 
person itself for selling purposes.

\section{Waste disposal}

The waste collected from every household is transported by vehicles and disposed of finally to the selected areas prescribed by local bodies. The disposal sites are mainly Landfill, riverbanks, depressed land/dumps, open pit, or temporary open piles. However, the municipality is somewhat polluted due to haphazard waste throwing in the street. The collected waste is disposed of in crude dumping sites in low-lying areas.

\section{Composting and Recycling}

Although Nepal's urban waste is primarily organic, only a small portion of it is composted or properly managed. Household composting and vermicomposting is practiced in some area like Kathmandu, Kritipur, Bhaktapur, etc. while scavengers and waste buyers usually collect other recyclable materials, such as metal, paper, and plastic, etc. Previously there was Bhaktapur Compost Plant, which was established by the municipality, composting about 10 percent of the city's waste which is closed due to the technical barrier and support. Recently PublicPrivate community Partnership has operated Decentralized Medium Scale Composting in Hetauda with a capacity of 3 tons/day and 500 sq. $\mathrm{m}$ of land. The compost is sold to farmers. There is an informal recycling center small paper recycling plant, which produces a variety of items such as folders, notebooks, photo albums, cards, etc. and enhancing the 3R principle. Many of the Municipality is actively promoting composting and recycling at the community and household level. A local NGO, Women Groups in partnership with the municipality, have initiated programs to promote composting. They have distributed buckets to households sorting organic and inorganic waste. After sorting, organic waste is composted in the drums in certain locations. They are also promoting ECOSAN toilets, which help reuse human feces and urine as fertilizer. Municipality also allows the reuse and recycle of the waste to scavengers at collection and disposal sites (Asian Development Bank, 2013).

\section{Social mobilization}

Awareness programs have been launched in all municipalities by various local, national, international, governmental, and private organizations. Programs, Interaction, and resource materials have been effectively running in various municipalities. Still the results of such programs are yet to be observed.

\section{Transportation}

According to the Solid Waste Management Act of 2011, the local bodies, such as municipalities, have been the responsible authority to collect, treat, and finally dispose of MSW. Municipalities are mainly responsible for the collection, transport, treatment, and final disposal of solid waste (Acharya, 2017). The wastes generated in Kathmandu are being collected by the different wards and taken to Teku Transfer Station, where it is loaded on bigger vehicles to dump in the dumping site. The challenge in other to manage proper transportation mechanisms, in urban as well as semi-urban sites is a lack of a proper transportation system. Because of the poor condition of roads, it is difficult to reach the source of generation (Shrestha, 2010). The number of wastes collecting containers and waste transporting trucks is not sufficient for the size of the population also (Ghimire, 2008).

\section{Landfill sites}

The major issue of the SWM for the local government is finding a suitable landfill site (Anderzen and Blees, 2003). The major landfill sites in Nepal namely the Sidsel landfill site, Karate Danda sanitary landfill site and Chihandada Landfill site, Xindanda sanitary 
landfill site (Pokhara). The composition of organic wastes was found to be as high as $61.86 \%, 49.12 \%$, and $65.81 \%$ a Sisdole, Pokhara, and Karate Danda landfill sites respectively. The waste management practices at Karaute Danda landfill were better compared to the other landfill as the sorting, composting and selling of recyclable and reusable wastes are done (Thapa and K.C., 2011). Kathmandu municipality is exploring a new alternative to manage solid waste with the current landfill site at Sisdol fast running out of its capacity (Ojha, 2017).

\section{Solid Waste Management Policies in Nepal}

Different Acts were created in different years to transfer the responsibilities of solid waste management. However, these Acts never went into effect completely (Dangi et al., 2017). There are still many shortcomings in the legal provisions related to SWM Nepal due to lack of awareness, technical knowledge, and prioritizations of the wastes by the concerned authorities, etc. The SWM issues are more serious in Nepal, especially after the 1980s due to the rapid growth of the human population and urbanization. With these, the government started to formulate and implement SWM policies to address the issues and associated problems, especially in the urban area (Alam et al., 2008). Among the acts and policies to Solid Waste Management, the 2011 Solid Waste Management Act and the 1996 National Policy on SWM are particularly relevant (Asian Development Bank, 2013).

\section{Solid Waste (Management and Resource Mobilization) Act, 1987}

It was the first law related to solid waste management in order to ensure the health convince of the common people by controlling the adverse impacts on pollution from solid waste. The salient features of these laws are:

- Under the provision of the Act Solid Waste
Management and Resource Mobilization Center (SWMRMC) was established as the first authorized body to manage the solid wastes of major cities.

- This act identified solid wastes as resources, and raise public awareness and public participation.

- The reuse, recycling, and reducing the wastes at the local level are prioritized.

- $\quad$ The provision of revenue-generating activities, such as the sale of fertilizer, biogas, briquette from the produced solid waste as well the collection of disposal fees, sweeping charges

- Despite being the first solid waste law in Nepal, it failed to provide effective legislation.

Municipality Act, 1992

The salient features of the acts are:-

- This act enforces waste collection, and proper disposal of wastes piled in streets, lanes, and footpath at the local level.

- It stated that the local entities can generate earnings from the sale of wastes carcasses.

- This act gives the municipality authority to collect the tax up to $50 \%$ from the parties that have profited from SWM-related business.

Environmental Protection Act (EPA), 1997

EPA was the first direct and comprehensive legislation concerning the preservation, protection, and management of the environment. The salient features of the acts are: -

- It emphasized various major environmental issues.

- Among them, likely provisions for the management of solid waste are prevention and control of pollution, provisions of environment inspector, compensation and punishment, etc.

- Formation of necessary terms and conditions in order to examine and inspect 
the waste generated from different sources, management, and transportation of waste and disposal, etc.

- Similarly, Environment Protection Rules were framed to implement necessary guidelines under the acts.

\section{Local Self Governance Act, 1999}

The salient features of the act are as follows:

- Local Self-Government Act highlighted the various issues associated with the management of solid wastes.

- The municipalities with a substantial urban population have the fundamental responsibilities in managing solid waste within their jurisdictions.

- The Ward Committee needs to arrange for disposal of waste, dirt keeping clean roads, ways, bridges, drainage, ponds, lakes, wells, temples, public places, etc.

- Similarly, the municipality needs to assist in environment protection acts by controlling water, air, and noise pollution generated within the municipality, and carry out sanitation programs in the municipality

- It authorizes the local government to prepare development plans to establish basics community infrastructures including public health and waste management.

\section{Solid Waste Management Act, 2011}

Solid Waste Management Act, 2011 is one of the comprehensive SWM laws to date in Nepal. The salient features of this act are as follows:

- Full responsibilities are provided to the local governments for SWM related services

- Similarly, the recognition of different types of waste (industrial, chemical, medical, and hazardous waste). Guidelines about how and who should manage the waste have also been defined.

- Waste should be segregated at source into organic and inorganic waste and the waste producer should bring the segregated waste to the collection center.

- The local government may designate a suitable collection center in each street or colony.

- Sanitary landfill sites should be prescribed by the local body for the final disposal of waste.

- Waste should be minimized at the source and further reduced by reusing and recycling.

- There should be an involvement of the private sector and community for effective SWM.

- Pollution control and the monitoring of SWM activities should be done as much as possible by the local body.

- SWM Council shall be formed to determine the policy to be adopted concerning SWM.

- Detailed functions, duties, and power of SWMTSC have been defined.

- Provisions for offenses and punishment to the violators.

Although the latest act is more comprehensive than any other preceding act, there are still some loopholes. The local governments are given full responsibility for SWM related services; however, they are not mandated to prepare the SWM plan as there is no clear deadline set for it

\section{Constitution of Nepal, 2015}

The salient features of the acts are as follows:-

- According to the Constitution of Nepal 2015, in article no. 30, there is a provision of the Right to a clean environment in which every citizen shall have the right to live in a clean and healthy environment.

- There is a provision for compensation to the victim regarding injury caused by environmental pollution or degradation.

- The law has legal provisions for a proper balance between the environment and development works of the nation.

Criminal (code) Act, 2017 
The salient features of the acts are:-

- In section 112, there is a provision, nobody can produce and discharge solid waste in an amount that can harm the environment.

- A person who is guilty or harassed according to Section 1 will be imprisoned for a year or up to ten thousand rupees or both will be punished.

\section{Local Government Operation Act 2017}

In the new federal context, there are now three levels of government i.e. federal, provincial and local. The new Constitution of Nepal 2015 involves provisions for local government institutions. The salient features of the acts are as follows: -

- The act has stipulated several arrangements related to authorities, duties, and responsibilities of local government plan formulation and implementation of judicial works.

- It clarifies the right of municipalities/rural municipalities to form local law regulations and responsibility for managing as well allocate the budget for environment pollution and hazard control; Solid waste management; water supply and sanitation etc.

\section{Environmental Protection Act, 2019}

Recently the Nepal government has preamble the amendment and integration of the Environment act. The salient features of the acts are as follows: -

- It has focused on the people's fundamental right to a clean and healthy environment.

- There is a provision of pollution control. All the polluting sources and people, tourist or any other activity should minimize production of hazardous obstruction or waste that impact on environment and maintain the standard of publishing information of Nepal government.

- The Act explicitly authorizes the Government of Nepal to set standards to reduce and regulate emission, hazardous waste, Pollution emitted by vehicles, equipment, industries, hotels, restaurants, and other institutions or activities.

- The Act puts restrictions on the export and import of hazardous substances/waste. The responsibility on the management, collection of hazardous waste should be taken by the concerned organization without impacts on the environment

- Provision of Funds, monitoring, compensation, and punishment and can prepare necessary guideline and standard under the framework of the act

A strong legal framework and appropriate laws and policies bear up the reduction, recycling, and environmental disposal of the MSW. The requirement for public health. There has been regulation in regards to MSW disposal on siting, design, construction, operation, and monitoring in Nepal. A large enhancement in solid waste management may be possible if the right policies apply and the right financial incentives may be proposed (Walls, 2006). The policies related to solid waste disposal are more important than the technical regulation. It may encourage alteration in disposal technologies and management practices (Nie, 2010). The evolution in disposal technologies and the industry demands effectiveness in policy making involve policy technology, industrial policy, energy policy, and investment policy (Yuan et al., 2006).

Developing countries like Nepal have to face serious environmental challenges concerning solid waste management. Disposal of solid waste in dumpsite indiscriminately located within urban areas has proved to be a problem to the nearby resident (Adam, El-gader, and Abdelrhman, 2015). Many research and studies have been done to examine the health and environmental effects arising from waste dumps. Such studies showed that a relationship exists between the health and environment (Atamila, 2010; Yongsi, 2008). Studies done 
by Yongsi (The World Bank, 2005), show that exposure to hazardous waste in dumpsites can negatively affect human health, children being the most vulnerable to the pollutants.

The major challenges for the SWM are source segregation, collection system, medical and e-waste management, transportation management system, landfill site, etc. The current solid waste problem can be solved if the existing laws and policies related to solid waste management are properly implemented by concerned bodies and agencies. Even though the laws related to the SWM have been barely carried out by the local government, the issues related to the community are very important to understand before implementing any policies in the public (Maskey, 2018).

\section{CONCLUSIONS}

Nepal has a long history of laws related to solid waste management. There has been the formulation of new laws and policies, however, most of them were poorly implemented by both government as well as from the citizens of the country. Lack of involvement of citizen in the strategy and poor decision-making process has made difficult to complete, functioning waste management service to be fulfilled. An attentive implementation of the current policies and laws will rally the immediate problem of SWM.

\section{REFERENCES}

Abduli, M (1995) Solid waste management in Tehran. Waste Management \& Research 13: 519531.

Acharya, H (2017) Municipal solid waste management; problem and opportunity. Retrieved October 12, 2018, from Nature Khabar: http://naturekhabar.com/en/ archives/3169

Adam B.A., A.A. Elgader and I.A. Abdelrhman (2015) Health and environmental impacts due to final disposal of solid waste in Zalingy town - central Darfur State - Sudan. International Journal of Research Granthaalayah 4(11): 92-100.

Adeoue G.O. and M.K.Sridhar (2003) Organomineral fertilizer from urban wastes: development in Nigeria. The Nigeria Field 68: 91-111.

Akenji, L., Y. Hotta, M. Bengtsson and S. Hayashi (2011) EPR policies for electronics in developing Asia: an adapted phase in approach. Waste management and Research 29(9): 919-930.

Alam R., M.A. Chowdhury, G.M. Hasan, B. Karanjit and L.R. Shrestha (2008) Generation, storage, collection and transportation of municipal solid waste - A case study in the city of Kathmandu, capital of Nepal. Waste Management 28: 1088-1097.

Anderzen C. and V. Blees (2003) Solid waste management in the city of Kathmandu, Nepal, Evaluation of the Vaxjo risk assessment model applied on Gokarna Lanfill Site. Kalmar: University of Kalmar, SE 39182.

ASCE (2013) Retrieved from 2009 Report Card for America's Infrastructure: https://www. infrastructurereportcard.org/2009/factsheet/solid-waste.html

Asian Development Bank (ADB) (2013) Solid Waste Management in Nepal: Current status and policy recommendations. Mandaluyong City, Philippines: ADB.

Atamila, M. (2010) Odor annoyance near waste treatment centers: A population-based study in Finland. Journal of Air and Waste Management Associatin 60(4): 412-418.

Australian Aid (2017) Diagnostic study of local governance in Federal Nepal 2017. Kathmandu: The Asia Foundation Partnership on Subnational Governance.

Babayemi, J.O. and K.T. Dayda (2009) Evaluation of solid waste generation, categories and disposal options in developng countries: A case study of Nigeria. Applied Science of Environmental Management 13(3): 83-88. 
CBS (2017) National Population and Housing Census 2011, Household and Population by Sex, Ward Level (Based on new structure of 753 local unit). Kathmandu, Nepal: Central Bureau of Statistics.

Dangi, M.B. (2009) Solid waste management in Kathmandu, Nepal: The anatomy of persistent failure. Doctoral dissertation, Johns Hopkins University, ProQuest LLC, Ann Arbor.

Dangi, M.B., E. Schoenberger and J.J. Bolang (2017) Assessment of environmental policy implementation in solid waste management in Kathmandu, Nepal. Waste management $\mathcal{E}$ research, 618-626.

Dos Muchangos L., A. Hanashima and A. Tokai (2015) Analyzing the structure of barriers to municipal solid waste management policy planning in Maputo city, Mozambique. Environmental Development 16: 76-89

Ghimire, H. (2008) An assessment of the environmnetal problems in the Kathmandu valley of Nepal. Ohio: Miami University.

Goncalves, A.T., F.T.Moraes, G.L. Marques, J.P. Lima, and R.D. Lima (2018) Urban solid waste challenges in the BRICS countries: A systematic literature review. Ambiente \& Agua - An Interdisciplinary Journal of Applied Science 13(2): 1-20.

Hoornweg, D. and P.T. Bhada (2012) What a waste, A global review of solid waste management.

ICIMOD (2007) Noudettu osoitteesta Kathmandu Valley Environment Outlook. Kathmandu: ICIMOD.

Joshi, R. and S. Ahmed (2016) Status and challenges of municipal solid waste management in India: A review

Keisham, S. and B. Paul (2015) A review on the recent scenario of municipal solid waste management in India. International Journal of Engineering Research and General Science 3(3): 528-542.

Maskey, B. (2018) Municipal solid waste management in Nepal: A case study of Gorkha Municipality. Doctoral dissertation,
Hiroshima University.

Meidiana, C. and T. Gamse (2011) The new waste law: Challenging opportunity for future landfill operation in Indonesia. Waste Management \& Research 29(1): 20-29.

Nie, Y. (2010) The technology and policy of urban solid waste disposal in China. International Journal of Environmental Studies, 183-193. doi:10.1080/00207231003683556

Ojha, A. (2017) ekantipur. Retrieved from Valley municipalities explore new lanfill site: http:/ / kathmandupost.ekantipur.com/news/201702-07/valley-municipalities-explore-newlandfill-site.html

Omari, A.M., B.N. Kichonge, K.N. Njau and P.L. Mltui (2014). Potential of Municipal Solid Waste, As Renewable Energy Source- A case study of Arusha, Tanzania. International Journal of Renewable Energy Technology Research, 3;6

Ovens, W. and F. Kitchin (2014) Case studies on the acquisition of urban land by municipalities from state owned companies and other organs of state. South African Cities Network 1-112.

Pattnaik, S. and M.V. Reddy (2010) Assessment of municipal solid waste management in Puducherry, India. Resources, Conservation and Recycling 54(8): 512-520.

Pokhrel, D. and T. Viraraghavan (2005) Municipal solid waste management in Nepal: practices and challenges. Waste Management 25: 555-562.

Practical Action Nepal (2008) Best practice on solid waste mangement of Nepalese cities. Kathmandu: Practical Action Nepal.

Rijal, K. and R. Sapkota (2014) Human population and environmental problems in Nepal: Population Monograph of Nepal .

Shakya, S.M. and B. Tuladhar (2013) State of municipal solid waste management in the municipalities of Nepal. In P. A., \& T. M., Municipal Solid Waste Management in Asia and the Pacific Islands. Environmetal Science and Engineering. (pp. 223-253). Singapore: Springer. 
Shrestha, M.E., J. Sartohadi J., M.K. Ridwan, and D.R. Hizbaron (2014) Converting Urban Waste into Energy in Kathmandu Valley: Barriers and Opportunities. Journal of Environmental Protection 5: 772-779.

Shrestha, R. (2010) Solid Waste Management in Kathmandu City, Nepal. Kathmandu, Nepal.

Sijapati, B.S. (2018) Comparative Environmental Law. Kathmandu: Pairavi Prakashan.

SWMTSC (2008) A Diagnostic Report on State of Solid Waste Management in Municipalities of Nepal. Solid Waste Management and Technical Support Centre.

Taylor, D.C. (2000) Policy incentives to minimize generation of municipal solid waste. Waste Management \& Research 18: 406-419.

Thapa, B. (2011) Solid waste management at landfill sites of Nepal. Indian Journal of Science and Technology 4(3): 164-166.

Thapa, B. and K.C. Ajay Kumar (2011) Solid waste management at landfill sites of Nepal. Indian Journal of Science and Technology 4(3): 164-166.

UN (2015) World urbanization prospects:The 2014. Department of Economic and Social Affairs.
Walls, M. (2006) The economcics of waste management: market structure and government policy. Washington DC: Urban Development Unit, Latin America and the Caribbean Region, World Bank, and Resources for the Future.

Wilson, D.C. (2012) Comparitive Analysis of SWM in 20 cities. Waste Management $\mathcal{E}$ Research 30(3): 237-254.

Wilson, D.C., P. Modak, R. Soos, C. Velis, A.C. Roger and O. Simonett (2015) Global waste Management outlook. Vienna, Austria: UNEP.

The World Bank (2005) Waste management in China: Issues and recommendatins. East Asia Infrastructure Development.

The World Bank (2019) Solid Waste Management. Understanding Poverty.

Yongsi, H.B. (2008) Environmental sanitation and health risks in tropical urban settings: Case study of household refuse and diarrhea in Yaounde-Cameroon. International Journal of Human and Social Science 3: 220-228.

Yuan, H., L. Wang, F. Su and G. Hu (2006) Urban solid waste Mangaement in China: Issues and Recommendations. Waste Management 1: 10521062. 